\title{
Клінічні дослідження \\ медичних наслідків аварії на Чорнобильській АЕС \\ згідно з базою даних сайту ClinicalTrials.gov
}

\section{І.П. Пастер}

ДУ «Інститут ендокринології та обміну речовин ім. В.П. Комісаренка НАМН України»

Резюме. 26 квітня 1986 р. на четвертому реакторі Чорнобильської атомної електростанції (ЧАЕС) сталася найбільш масштабна техногенна аварія в історії людства. Мета — представити інформацію про клінічні дослідження медичних наслідків аварії на ЧАЕС. Результати. Станом на 31 березня 2020 р. на сайті ClinicalTrials.gov була розміщена інформація про 6 клінічних досліджень із медичних наслідків аварії на ЧАЕС. Середня тривалість досліджень становить 15 років і 9 місяців, а 2/3 із них виконуються понад 20 років. Поточний статус досліджень: «завершено» - 3 дослідження, «набір», «активний, без набору» і «призупинено» - по 1 дослідженню. 4 клінічних дослідження проводяться в Україні: 3 - на базі ДУ «Національний науковий центр радіаційної медицини НАМН України» 1 - на базі ДУ «Інститут ендокринології та обміну речовин ім. В.П. Комісаренка НАМН України»; 1 дослідження проводиться в Республіці Білорусь на базі Республіканського науково-практичного центру радіаційної медицини та екології людини (м. Гомель), а 1 завершене дослідження проводилося в Сполучених Штатах Америки на базі Національного інституту раку (National Cancer Institute). У всіх дослідженнях головний дослідник є співробітником National Cancer Institute (США). Спонсором усіх досліджень $\in$ National Cancer Institute (США). Загальна кількість учасників клінічних досліджень становила 51051 особу (мінімальна - 673, максимальна - 23 143, середня - 8508). Тип дослідження у всіх випадках був обсерваційний. $3 а$ моделлю дослідження розподіл наступний: когортне дослідження - 2 дослідження, дослідження «випадокконтроль» - 2 дослідження, дослідження сімей - 1 дослідження (для одного дослідження інформація відсутня). За часовою перспективою дослідження були ретроспективними - 3 дослідження, проспективними і по-

* Адреса для листування (Correspondence): ДУ «Інститут ендокринології та обміну речовин ім. В.П. Комісаренка НАМН України», вул. Вишгородська, 69, м. Київ, 04114,

україна. E-mail: pasteur@ukr.net

() І.П. Пастер 
Огляди

перечними - по 1 дослідженню (для одного дослідження інформація відсутня). За методом вибірки клінічні дослідження були випадковими (2 дослідження) і невипадковими (3 дослідження); для одного дослідження інформація відсутня. Представлено огляд 20 публікацій за результатами 5 клінічних досліджень. Висновок. На сайті ClinicalTrials.gov зареєстрована вкрай мала кількість клінічних досліджень медичних наслідків аварії на ЧАЕС.

Ключові слова: аварія на Чорнобильській АEC, медичні наслідки, клінічні дослідження.

\section{Актуальність проблеми медичних наслід- ків аварії на Чорнобильській АЕC \\ 26 квітня 1986 р. в результаті аварії на} четвертому реакторі ЧАЕС стався викид величезної кількості радіоактивних речовин у навколишнє середовище, які у вигляді радіоактивних опадів випали на великих територіях України, Білорусі і Російської Федерації. Особливу небезпеку для організму людини становить радіоактивний йод, який надходить аліментарним або інгаляційним шляхом та інтенсивно накопичується в щитоподібній залозі (ЩЗ), викликаючи порушення в $\dddot{1}$ роботі. На жаль, найчутливішою до негативного впливу радіойоду є ЩЗ дітей і підлітків [1], що спричинило істотне збільшення кількості виявлених випадків захворювання на злоякісні новоутворення ЩЗ серед цього контингенту [2]. Ситуацію значно ускладнив дефіцит йоду на переважній більшості найбільш радіаційно забруднених територій [3], що зумовило ще інтенсивніше накопичення радіойоду в ЩЗ. Оцінка біологічного ризику від радіоізотопів йоду є вкрай важливою для системи охорони здоров'я через подальше медичне використання ${ }^{131} \mathrm{I}$, а також через вельми значну частку радіоізотопів йоду в структурі радіонуклідних викидів під час ядерних аварій або ядерних вибухів [4].

Для детального вивчення медичних наслідків впливу іонізувального опромінення Щ3 під час аварії на ЧАЕС застосовуються спеціальні когортні дослідження на радіоактивно забруднених територіях України, Білорусі і Російської Федерації [5].

Предметом цього огляду є інформація про клінічні дослідження медичних наслідків аваpiï на ЧАЕС згідно бази даних сайту ClinicalTrials.gov.
Клінічні дослідження медичних наслідків аварії на Чорнобильській AEC

Аналіз клінічних досліджень медичних наслідків аварії на ЧАЕС проведено за базою даних сайту ClinicalTrials.gov [6].

ClinicalTrials.gov - це веб-ресурс, який було розроблено під егідою Міністерства охорони здоров’я та соціальних служб США (U.S. Department of Health and Human Services) спільно 3 Національним інститутом здоров'я (National Institute of Health) та Управлінням із продовольства і медикаментів (Food and Drug Administration) [7].

Станом на 31 березня 2020 р. на офіційному сайті ClinicalTrials.gov була розміщена інформація про 334665 досліджень, які проводяться в 211 країнах світу, з яких 165158 досліджень (49\% від загальної кількості) за межами США, 112783 (34\%) - у США, 17351 (5\%) - спільно в США та інших країнах і для 39373 (12\%) досліджень інформація про місце проведення дослідження не була надана спонсором [8].

Кількість клінічних випробувань (263402 записи або 79\% від загальної кількості зареєстрованих досліджень) значно превалювала над кількістю клінічних спостережень (69777 або 21\%) і включала 146871 запис про вивчення медикаментів або біологічних ефектів, 85440 записів - поведінкових реакцій, 27671 запис - хірургічних процедур і 33940 записів - приладів і пристроїв [8]. 622 записи зареєстрованих досліджень мали розширений доступ.

Станом на 31 березня 2020 р. пошук на офіційному сайті ClinicalTrials.gov за ключовими словами «Chornobyl» i «Chernobyl» виявив інформацію про 6 клінічних досліджень із медичних наслідків аварії на ЧАЕС (табл.) [9]. 
Таблиця. Клінічні дослідження медичних наслідків аварії на Чорнобильській АEC

Table. Clinical studies of the medical consequences of the Chornobyl accident

\begin{tabular}{|c|c|c|c|c|c|}
\hline NN & $\begin{array}{l}\text { Код і статус } \\
\text { дослідження } \\
\text { NCT number } \\
\text { and status }\end{array}$ & $\begin{array}{l}\text { Назва дослідження } \\
\text { Title }\end{array}$ & $\begin{array}{l}\text { Виконавці дослідження } \\
\text { Investigators }\end{array}$ & $\begin{array}{l}\text { Медична характеристика } \\
\text { дослідження } \\
\text { Characteristic }\end{array}$ & $\begin{array}{l}\text { Дизайн } \\
\text { дослідження } \\
\text { Design }\end{array}$ \\
\hline 1 & $\begin{array}{l}\text { NCT00339274 } \\
(999900024 \\
\text { OH00-C-N024) } \\
14.10 .1999- \\
16.03 .2012 \\
\text { Завершено }\end{array}$ & The Chernobyl Tissue Bank & $\begin{array}{l}\text { National Cancer Institute } \\
\text { (Bethesda, USA) } \\
\text { Louise Brinton, Ph.D. (National } \\
\text { Cancer Institute) } \\
\text { National Cancer Institute } \\
\text { (Bethesda, USA) }\end{array}$ & $\begin{array}{l}\text { Стан: Навколишнє середовище } \\
\text { Результат: - } \\
\text { Популяція: - (4000 суб'єктів) }\end{array}$ & $\begin{array}{l}\text { Обсерваційний } \\
- \\
- \\
-\end{array}$ \\
\hline
\end{tabular}
16.03.2012

2 NCT00339716 Scientific Protocol for the (999900021, Study of Thyroid Cancer OH95-C-N021) and Other Thyroid Disease 21.03.1994- in Belarus Following the Завершено Chernobyl Accident 03.2020

3 NCT00341016 Scientific Protocol for (999996030, the Study of Leukemia OH96-C-N030) and Other Hematologic 26.08.1996- Diseases Among CleanЗавершено ир Workers in Ukraine $02.2020 \quad$ Following the Chernobyl Accident

4 NCT00341094 Scientific Protocol for the (999995020, Study of Thyroid Cancer OH95-C-N020) and Other Thyroid Diseases 01.05.1995- in Ukraine Following the Активний, без Chernobyl Accident набору 07.11 .2019

5 NCT01265381 Thyroid Cancer Among (999911049, Chornobyl Clean-up 11-C-N049) Workers in Ukraine: Pilot 22.12.2010- Study Зупинено 03.2019

6 NCT02566161 Parental Irradiation (999915199, 15-C-N199) 01.10 .2015 Набір 08.08.2019 of Ukrainian Cleanup Offspring (Trio Study)
Республиканский научнопрактический центр радиационной медицины и экологии человека (Гомель, Республика Беларусь) Kiyohiko Mabuchi, M.D. (National Cancer Institute) National Cancer Institute (Bethesda, USA)

ду «Національний науковий центр радіаційної медицини НАМН України» (Київ, Україна)

Kiyohiko Mabuchi, M.D. (National Cancer Institute) National Cancer Institute (Bethesda, USA)

ДУ «Інститут ендокринології та обміну речовин ім. В.П. Комісаренка НАМН України» (Київ, Україна) Elizabeth K. Cahoon (National Cancer Institute) National Cancer Institute (Bethesda, USA)
ДУ «Національний науковий Стан: Злоякісні новоутворення ЩЗ центр радіаційної медицини Результат: Радіаційний ризик НАМН України» (Київ, Україна) Kiyohiko Mabuchi, M.D. (National Cancer Institute) National Cancer Institute (Bethesda, USA)

ДУ «Національний науковий центр радіаційної медицини Workers and Evacuees and НАМН України» (Київ, Germline Mutations in Their Україна)

Amy Berrington, M.D. (National Cancer Institute) National Cancer Institute (Bethesda, USA)
Стан: Злоякісні новоутворення Щ3; доброякісні новоутворення Щ3; нетиреоїдні злоякісні новоутворення

Результат: Радіаційно-зв'язаний ризик виникнення доброякісної та злоякісної патології Щ3; радіаційний ризик

Популяція: Суб'єкти, які були опромінені ${ }^{131}$ у у віці до 18 років; суб'єкти, які були опромінені ${ }^{131}$ in utero (19456 суб'єктів)

Стан: Лейкемія

Обсерваційний

Результат: Ризик лейкемії, пов'язаної Випадокз радіаційним опроміненням контроль Популяція: Українські ліквідатори наслідків аварії на ЧАЕС (1 779 суб'єктів)

Ретроспективне Випадкова вибірка

Стан: Злоякісні новоутворення Щ3; доброякісні новоутворення Щ3; нетиреоїдні злоякісні новоутворення

Результат: Радіаційно-зв'язаний ризик виникнення доброякісної та злоякісної патології Щз; радіаційний ризик

Популяція: Суб'єкти, які були опромінені ${ }^{131}$ І у віці до 18 років; суб'єкти, які були опромінені ${ }^{131}$ in utero (23 143 суб'єкти)

Обсерваційний Когортне Проспективне Невипадкова вибірка

Обсерваційний Когортне Ретроспективне Невипадкова вибірка

Обсерваційний Випадокконтроль Ретроспективне Випадкова вибірка аварії на ЧАЕС

Популяція: Українські ліквідатори наслідків аварії на ЧАЕС (673 суб'єкти)

Стан: Генетика

Обсерваційний Результат: Зв'язок доконцептуальної Family-Based дози опромінення гонад батьків зі Поперечний спадковими генетичними мутаціями Невипадкова Популяція: Діти, які були народжені вибірка від батьків, які зазнали впливу іонізуючого випромінювання внаслідок аварії на ЧАЕС, через 42 та більше тижнів після останнього значного впливу радіації (2000 суб'єктів) 
Огляди

\section{Пояснення до таблиці:}

колонка «Код і статус дослідження»: ідентифікатори в системі ClinicalTrials.gov та в інших системах, дата початку ізавершення дослідження, статус дослідження і дата останньої верифікації медичної документачії дослідження;

колонка «Назва дослідження»: офіційна назва дослідження; колонка «Виконавці дослідження»: базова організація виконання дослідження, головний дослідник і спонсор дослідження; колонка «Медична характеристика дослідження»: стан або захворювання, показник результату дослідження, досліджувана популячія і кількість суб'єктів дослідження;

колонка «Дизайн дослідження»: mun дослідження, mun моделі обсервачійного дослідження, часова перспектива дослідження івибірковий метод дослідження;

стан (стан або захворювання) -хвороба, розлад, синдром, травма або інші проблеми, пов'язані зі здоров'ям, такі як ризики для здоров'я, тривалість або якість життя;

результат (показник результату) - упротоколі клінічного дослідження запланована очінка результатів, якає найважливішою для оцінки ефекту втручання або лікування більшість клінічних досліджень мають один основний показник результатів, але деякі дослідження мають більше одного); популяція (досліджувана популяція) — група осіб в клінічному дослідженні, які відібрані на підставі критеріїв включення і виключення, і які відносяться до змінних, що вивчаються; Всі дані в таблиці наведені за станом на 31 березня 2020 року.

\section{Explanation to the table:}

column «NCT number and status»: ClinicalTrials.gov identifier and other ID numbers, start and finish date, current status (previous status in case of current status «unknown») and verification date;

column «Title»: Official title;

column «Investigators»: Locations, collaborators, principal investigator and sponsor;

column «Characteristic»: Detailed description of process, primary outcome measures, secondary outcome measures and estimated enrollment;

column «Design»: Intervention, type, allocation, intervention model, masking, primary purpose and phase;

All data in the table are as of March 31, 2020.

Аналіз дат початку дослідження (дати, коли першого учасника було зараховано до клінічного дослідження) показав, що переважна більшість клінічних досліджень (4 з 6) були зареєстровані понад 20 років тому: у 1994, 1995, 1996 і 1999 pp. Ще 2 дослідження були зареєстровані у 2010 і 2015 pp.

На цей момент завершене тільки одне клінічне дослідження NCT00339274, тривалість якого становила 12 років і 5 місяців. Датою завершення чотирьох інших клінічних досліджень (дата, коли останній учасник клінічного дослідження був обстежений або зазнав втручання (тобто останнього відвідування останнього учасника)) був вказаний 2020 р. Середня тривалість цих досліджень вже становить 15 років і 9 місяців (від 4 років і 6 місяців до 25 років і 11 місяців). Дані для клінічного дослідження NCT00341094 не представлені.

Поточний статус виконання клінічних досліджень: «завершено» (дослідження заверше- но нормально, учасників більше не обстежують та не лікують) - 3 дослідження (50,0\% від загальної кількості), «набір» (проводиться набір учасників дослідження), «активний, без набору» (дослідження триває, учасники проходять обстеження i/або лікування, потенційних учасників наразі не набирають) i «призупинено» (дослідження достроково призупинено i не буде продовжено; учасників більше не обстежують та не лікують) - по 1 дослідженню (по 16,7\% ). Останні верифікації медичної документації досліджень на сайті ClinicalTrials.gov (остання дата, коли спонсор дослідження або дослідник підтвердив точність та актуальність інформації про клінічне дослідження) були виконані у 2019 р. - для 3 досліджень, у 2020 р. - для 2 досліджень і у 2012 р. - для 1 дослідження.

4 клінічних дослідження проводяться в Україні, причому 3 з них - на базі ДУ «Національний науковий центр радіаційної медицини НАМН України» і ще 1 - на базі дУ «Інститут ендокринології та обміну речовин ім. В.П. Комісаренка НАМН України». Клінічне дослідження NCT00339716 проводиться в Республіці Білорусь на базі Республіканського науково-практичного центру радіаційної медицини та екології людини (м. Гомель), а завершене клінічне дослідження NCT00339274 проводилося в Сполучених Штатах Америки на базі Національного інституту раку (National Cancer Institute).

У всіх клінічних дослідженнях спонсором (організація або особа, яка ініціює дослідження та має повноваження їх контролювати) або співвиконавцем (організація, яка не є спонсором, але яка забезпечує підтримку клінічного дослідження шляхом фінансування, розробкою, впровадженням, аналізом даних або звітуванням) було вказано Національний інститут раку.

Загальна кількість учасників клінічних досліджень становила 51051 особу (мінімальна - 673, максимальна - 23143 , середня 8508).

Тип дослідження у всіх випадках був обсерваційний (учасників визначають як належних до досліджуваних груп та оцінюють за результатами біомедичних та медичних досліджень; учасники можуть отримувати діагностичні, терапевтичні та інші види призначень, але 
дослідник не призначає учасникам конкретні втручання і/або лікування).

Типом обсерваційного дослідження є peєстр пацієнтів (дослідження, що збирає інформацію про медичний стан i/або лікування пацієнтів, щоб оцінити їх вплив на пацієнтів у реальному світі).

Агенство з якості досліджень в області охорони здоров'я (The Agency for Healthcare Research and Quality) визначає реєстр пацієнтів як організовану систему, яка застосовує методи спостереження для проспективного отримання однорідних даних (клінічних та інших) для популяції, яка визначена конкретним розладом/захворюванням, станом (зокрема, сприйнятливістю до розладу) або схильністю до впливу (у тому числі, продуктів, послуг охорони здоров’я i/або процедур) і яка слугує певній науковій, клінічній або політичній меті $[6,10]$. Реєстри пацієнтів можуть слугувати одній єдиній меті або бути програмами по отриманню поточних даних, які стосуються одного або ряду питань.

За моделлю обсерваційного дослідження (загальна схема стратегії виявлення та подальшої роботи з учасниками під час дослідження) розподіл наступний: когортне дослідження (дослідження групи осіб, спочатку визначеної та складеної, із загальними характеристиками (наприклад, рік народження), які розглядають або простежують протягом певного періоду часу) - 2 дослідження, дослідження «випадок-контроль» (порівняння групи осіб із конкретними характеристиками (наприклад, умовами або впливами) порівняно з групою осіб із різними характеристиками, однак в іншому схожих) -2 , дослідження сімей -1 (для клінічного дослідження NCT00339274 інформація відсутня).

За часовою перспективою клінічні дослідження були ретроспективними (аналіз характеристик за архівними даними для сформованої групи суб'єктів) - 3 дослідження, проспективними (аналіз періодичних спостережень, які були отримані переважно після формування групи суб'єктів) і поперечними (аналіз даних на конкретний момент часу) по 1 дослідженню (для клінічного дослідження NCT00339274 інформація відсутня).

За методом вибірки клінічні дослідження були випадковими (вибірка включає випадковий відбір, що дозволяє робити статистичні висновки про всю групу) - 2 дослідження і невипадковими (вибірка включає невипадковий відбір на основі зручності або інших критеріїв, що дозволяє легко збирати вихідні дані) - 3 (для клінічного дослідження NCT00339274 інформація відсутня).

Майже всі клінічні дослідження (за винятком, NCT00339274) опублікували результати, хоча раніше було показано, що результати 25$50 \%$ клінічних досліджень не були опубліковані, а середній час на публікацію становить приблизно 2 роки [11].

\section{The Chernobyl tissue bank}

Опис дослідження:

Міжнародний скоординований підхід за підтримки урядів Білорусі, Російської Федерації, України, Національного інституту раку США (National Cancer Institute), Свропейської комісії (European Commission), японського Меморіального фонду охорони здоров'я Сасакава (Sasakawa Memorial Health Foundation of Japan) і Всесвітньої організації охорони здоров'я (World Health Organization) для допомоги Білорусі, Російській Федерації та Україні у створенні власного банку даних і тканин ЩЗ, а також забезпеченні використання тканин і нуклеїнових кислот для вивчення наслідків аварії на ЧАЕС [12].

Публікащї: інформація відсутня.

Scientific protocol for the study of thyroid cancer and other thyroid disease in Belarus following the Chernobyl accident

Опис дослідження.

Для детального вивчення медичних наслідків аварії на ЧАЕС створена когорта з 15000 мешканців Білорусі, яким на момент аварії на ЧАЕС було до 18 р. і яким у травні-червні 1986 р. було проведено радіометрію Щ3 [13].

Обстеження складалося з реєстрації, аналізу крові (визначення рівнів тиреотропного гормону, вільного тироксину, тиреоглобуліну, іонізованого кальцію, антитіл до тиреопероксидази та тиреоглобуліну - лише в перші чотири цикли) та визначення рівня йоду в сечі, ультразвукового обстеження ЩЗ, консультації лікаря-ендокринолога, а також опитування 3 метою реконструкції доз опромінення ЩЗ. За необхідності призначали додаткове поглиблене обстеження (зокрема, тонкоголкову 
аспіраційну пункційну біопсію Щ3) і відповідне лікування. Рак Щ3 підтверджували експертним патологічним дослідженням тканини, отриманої під час операції.

Активний третій скринінг було завершено у вересні 2006 р. Ідентифіковано 163 випадки раку ЩЗ. Виявлення нових випадків захворювання на рак ЩЗ та інших ракових захворювань ведеться шляхом підключення до Білоруського реєстру раку.

Дозу опромінення ЩЗ оцінювали шляхом реконструкції динаміки радіоактивного забруднення території, а також місця перебування, харчових характеристик та способу життя кожної людини протягом усього періоду впливу.

Дані будуть проаналізовані, щоб оцінити взаємозв'язок між захворюваннями Щ3, особливо раком, та дозою опромінення Щ3 радіойодом. Основна увага буде зосереджена на аналізі залежності «доза-відгук» зі стратифікацією за статтю, віком на момент експозиції, географічним регіоном і часом після виявлення. Також будуть враховані додаткові фактори, наприклад, використання йодиду калію в якості профілактичного заходу, а також невизначеність оцінок дози опромінення.

Очікується отримати нові знання про канцерогенну ефективність ${ }^{131}$ I порівняно $з$ показником рентген- та гамма-випромінювання, що дозволить заповнити значну прогалину у світових знаннях про радіаційні ефекти та розробити рекомендації щодо радіаційного захисту.

\section{Публікащї}

Описана оцінка невизначеностей у реконструйованих дозах опромінення ЩЗ за рахунок ${ }^{131} \mathrm{I}$ [14]. Було проведено по 1000 обчислень когортних доз ЩЗ із використанням процедури Монте-Карло. Арифметичне середне значення стохастичних доз опромінення Щ3 для всієї групи становило 0,68 Гр, для двох третин когорти - менше 0,5 Гр. Геометричні стандартні відхилення стохастичних доз змінювалися серед членів когорти від 1,33 до 5,12 із середнім арифметичним значенням 1,76 та середнім геометричним значенням 1,73. Основними джерелами невизначеностей в оцінці доз опромінення ЩЗ є невизначеності мас ЩЗ суб'єкта та невизначеності оцінок вмісту радіойоду в ЩЗ під час їі моніторингу. Внесок загальних помилок у загальну невизначеність був невеликим.
Встановлено статистично значуще $(\mathrm{p}<0,001)$ зростання кривої «доза-відгук» для поширеності раку ЩЗ, незалежно від використовуваного методу коригування регресії (метод калібрування регресії, метод максимальної правдоподібності Монте-Карло і баєсівський метод) [15]. Без коригування похибки ексцес співвідношення шансів становив $1,51 \mathrm{\Gamma p}^{-1}$ (95\% довірчий інтервал $0,53,3,86)$; метод максимальної правдоподібності Монте-Карло дав ексцес співвідношення шансів 1,48 $\Gamma^{-1}$ (95\% довірчий інтервал $0,53,3,87)$, байєсівський метод $-1,16 \Gamma_{\mathrm{p}}^{-1}(95 \%$ байєсівський довірчий інтервал 0,20, 4,32). Були значні граничні значення $(\mathrm{p}=0,102)$, що модифікують залежність дози опромінення від статі, але відсутні значущі модифікуючі ефекти віку суб'єкта на момент аварії на ЧАЕС або його віку на момент скринінгу ( $\mathrm{p}>0,2)$.

У когорті з 11613 осіб виявлена значна лінійна дозова залежність для 38 патологічно підтверджених фолікулярних аденом [16]. Ексцес співвідношення шансів на Гр становив $2,22$ (95\% довірчий інтервал $0,41,13,1)$ і був подібний у чоловіків і жінок. Показник значно зменшився зі збільшенням віку на момент опромінення $(\mathrm{p}<0,01)$, а найвищі ризики опромінення оцінювали для осіб, які зазнали впливу у віці $<2$ років.

Scientific protocol for the study of leukemia and other hematologic diseases among cleanup workers in Ukraine following the Chernobyl accident

Опис дослідження

Основна мета цього дослідження - вивчення ризику розвитку лейкемії серед чоловіків працездатного віку як функції радіаційного випромінювання та порівняння його з розрахунку на одиницю дози з відповідним показником у постраждалих від атомного бомбардування, підданих фактично миттєвому випромінюванню; перевірка гіпотези про залежність ризику виникнення множинної мієломи та мієлодисплазії від дози опромінення [17].

Вторинна мета - виявлення будь-яких модифікаторів ризику, включно з часом після впливу, віком на момент впливу тощо; збір і зберігання букальних клітин приблизно від 2000 ліквідаторів із дозами опромінення понад 1 Гр для можливого використання в майбутніх молекулярних ДНК-дослідженнях. 
Дослідження проводиться в когорті приблизно зі 100000 чоловіків працездатного віку українських учасників ліквідації наслідків аварії (далі - УЛНА) на ЧАЕС, які вперше працювали навколо електростанції між 1986 та 1990 рр., отримали середні дози опромінення кісткового мозку приблизно 80-100 мГр та були внесені до Чорнобильського державного реєстру.

Встановлено 75 підтверджених випадків лейкемії та 12 випадків множинної мієломи.

\section{Публікащї}

У рамках епідеміологічного дослідження лейкемії та інших супутніх захворювань крові серед УЛНА окремі дози опромінення кісткового мозку були оцінені для 572 випадків та контролю [18]. За допомогою моделі реконструкції дози в стохастичному варіанті, розробленої для приблизно половини досліджуваних без записів про дози, вдалося встановити арифметичні середні індивідуальні поглинуті дози для кісткового мозку (від 0,00004 до 3300 мГр, середне значення 87 мГр).

Оцінка відносного ризику хронічної лімфоцитарної лейкемії та не хронічної лімфоцитарної лейкемії від тривалих впливів іонізуючого випромінювання з низькою дозою в когорті з 110645 УЛНА дозволила виявити значну лінійну відповідь на дозу для всіх лейкозів (137 випадків, ексцес відносного ризику на Гр=1,26 (95\% довірчий інтервал 0,03, 3,58) [19]. 16\% випадків лейкемії (18\% хронічної лімфоцитарної лейкемії та 15\% не хронічної лімфоцитарної лейкемії) було віднесено до радіаційного впливу і зроблено висновок про їх радіочутливість.

Дослідження впливу професійних факторів та способу життя УЛНА на ризик розвитку лейкемії не виявили чіткої асоціації ризику захворювання 3 палінням або вживанням алкоголю, але виявили вдвічі підвищений ризик виникнення не хронічної лімфоцитарної лейкемії при порівнянні 3 виробничим впливом нафтопродуктів (співвідношення шансів $=2,28 ; 95 \%$ довірчий інтервал 1,13, 6,79) [20]. Ризики були особливо високими для мієлоїдних лейкозів. Для хронічного лімфоцитарного лейкозу не виявлено асоціацій з іншими факторами ризику, окрім радіації.

Scientific protocol for the study of thyroid cancer and other thyroid diseases in Ukraine following the Chernobyl accident

Опис дослідження

Для детального вивчення медичних наслідків аварії на ЧАЕС створена основна когорта з 13243 мешканців України: а) які на момент аварії постійно проживали або тимчасово перебували в місті Прип'ять або в одному з восьми найбільш радіаційно забруднених районах Житомирської (Народицький та Овруцький райони), Київської (Іванківський, Поліський та Чорнобильський райони) та Чернігівської (Козелецький, Ріпкинський та Чернігівський райони) областей, б) яким на момент аварії було до 18 років, в) яким у перші тижні після аварії було проведено радіометрію ЩЗ та г) які були відібрані методом випадкової вибірки, а також когорта in utero 32582 мешканців України, які були опромінені внутрішньоутробно [21].

Обстеження основної когорти проводили в 5 циклів: квітень 1998 р. - грудень 2000 р., березень 2001 р. - грудень 2003 р., травень 2003 р. - квітень 2005 р., травень 2005 р. - квітень 2007 р., квітень 2012 р. - грудень 2015 р.; когорти in utero - травень 2003 р. - квітень 2005 р. і квітень 2012 р. - грудень 2015 р.

Обстеження складалися 3 реєстрації, аналізу крові (визначення рівнів тиреотропного гормону, вільного тироксину, тиреоглобуліну, іонізованого кальцію, антитіл до тиреопероксидази та тиреоглобуліну - лише в перші чотири цикли) та визначення рівня йоду в сечі, ультразвукового обстеження ЩЗ, консультації лікаря-ендокринолога, а також опитування з метою реконструкції доз опромінення ЩЗ. За необхідності призначали додаткове поглиблене обстеження в клініці ДУ «Інститут ендокринології та обміну речовин ім. В.П. Комісаренка НАМН України» (зокрема, тонкоголкову аспіраційну пункційну біопсію ЩЗ) і відповідне лікування. Рак ЩЗ підтверджували експертним патологічним дослідженням тканини, отриманої під час операції.

Крім цього, із метою підвищення точності реконструкції дози опромінення ЩЗ були опитані батьки членів основної когорти, які на момент аварії були віком до 10 років. Дозу опромінення Щ3 оцінювали шляхом реконструкції динаміки радіоактивного забруднення території України за допомогою моделі атмосферного перенесення LEDI (модель дифузії Лагранжа-Ейлера), а також місця перебування, харчових характеристик та способу життя кожного суб'єкта протягом усього періоду опромінення. Дози опромінення ЩЗ in utero розраховували за допомогою 
багатокомпонентної моделі обміну йоду з урахуванням активності ${ }^{131}$ І у Щ3 матері.

До протоколу було внесено кілька поправок: iз 2008 р. нові випадки раку ЩЗ почали також встановлювати шляхом лінкеджу з базою даних Національного реєстру раку України; продовжили піддослідження, що передбачає додаткове наступне обстеження тих членів когорти, у яких була діагностована доброякісна вузлова патологія ЩЗ протягом попередніх скринінгових циклів; започаткували генетичні дослідження раку ЩЗ і пілотне дослідження геномної характеристики раку ЩЗ.

\section{Публікаиії}

За результатами клінічного дослідження опубліковано 45 статей, анотації яких містяться в трьох оглядах [22-24].

Під час першого скринінгового обстеження членів когорти виявлено 3612 випадків тиреоїдної патології, серед яких злоякісні новоутворення Щ3 становили 1,60\%, фолікулярна аденома $-0,75 \%$, дифузний нетоксичний зоб $81,01 \%$, дифузний токсичний зоб - 0,22\%, нетоксичний вузловий зоб - 6,87\%, автоімунний тиреоїдит $-7,28 \%$, поопераційний гіпотиреоз $1,88 \%$ і набутий гіпотиреоз - 0,39\% [25].

Поширеність тиреоїдної патології серед членів когорти становила 273,31 випадку на 1000 суб'єктів [25]. Встановлено пряму залежність поширеності тиреоїдної патології від віку членів когорти. Поширеність усіх видів тиреоїдної патології (за винятком дифузного нетоксичного зоба) була вищою серед членів когорти жіночої статі. Встановлено відносний ризик виникнення тиреоїдної патології серед членів когорти залежно від місця постійного мешкання, віку на момент обстеження та статі.

Протягом другого-четвертого скринінгів Проекту та 73004 людино-років спостереження в членів когорти було виявлено 65 випадків раку Щ3 [26]. У відносній та абсолютній моделях ризику співвідношення «доза-ефект» узгоджується з лінійним, хоча модель відносного ризику описує дані ліпше, ніж модель абсолютного ризику.

Ексцес відносного ризику в перерахунку на Гр становив 1,91 (95\% довірчий інтервал, 0,43$6,34)$, а ексцес абсолютного ризику в перерахунку на $10^{4}$ людино-років/Гр - 2,21 (95\% довірчий інтервал, 0,04-5,78) [26]. Ексцес відносного ризику в перерахунку на Гр значною мірою залежав від області мешкання, але не залежав від часу після виявлення, йодної профілактики, йодного статусу, статі, віку члена когорти або розміру його пухлини.

Відмічено значне збільшення захворюваності на рак ЩЗ у членів когорти віком від 19 до 46 років на момент операції, яке зберігалося до 2014 року, а рівень захворюваності в шести найбільш забруднених радіойодом регіонах перевищував показник у 21 менш забрудненій області [27]. Патогістологічний аналіз 2634 карцином Щ3 показав, що папілярна карцинома ЩЗ є найбільш поширеним типом раку ЩЗ в усі досліджені періоди. Зі збільшенням часу після аваpiї папілярні карциноми з домінуючою папілярною структурою росту мають більш виражені інвазійні властивості, але, як правило, пухлини явно стають менш агресивними, що є важливим і сприятливим для поопераційного прогнозу.

Аналіз впливу ${ }^{131} \mathrm{I}$ на розвиток плода в когорті з 2582 осіб з індивідуально оціненими дозами на Щ3 (середня доза = 72,6 мГр) показав помітно підвищений, проте не значущий, дозозалежний ризик розвитку раку ЩЗ (ексцес співвідношення шансів $/ \Gamma \mathrm{p}=3,91)$; виражений, значущий взаємозв'язок між дозою ${ }^{131} \mathrm{I}$ на Щ3 і виявленими великими доброякісними вузлами ( $\geq 10$ мм) (ексцес співвідношення шансів/Гр $=4,19,95 \%$ довірчий інтервал 0,68, 11,62; p=0,009), проте ризик невеликих вузлів (<10 мм) не збільшувався (ексцес співвідношення шансів $/ \Gamma \mathrm{p}=0,34$, 95\% довірчий інтервал 0,67, 2,24; p=0,604). [28].

Аналіз антропометричних ефектів ${ }^{131}$ I виявив значуще дозозалежне зменшення окружності голови плода $(-1,0 \mathrm{~cm} / \Gamma \mathrm{p}, \mathrm{p}=0,005)$ та окружності грудної клітки $(-0,9$ см/Гр, $\mathrm{p}=0,023)$, а також подібне, але не вірогідне зменшення неонатальної довжини $(-0,6$ см/Гр, $\mathrm{p}=0,169)$; значне зростання тривалості гестації зі збільшенням дози (0,5 тижня/Гр, $\mathrm{p}=0,007)$; відсутність суттєвого ( $>>0,1)$ ефекту дози на масу тіла на момент народження [29].

Thyroid cancer among Chornobyl clean-up workers in Ukraine: Pilot study

Опис дослідження

Задачі дослідження полягали в наступному [30]:

- оцінити радіаційний ризик захворювання на рак ЩЗ серед 150000 УЛНА чоловічої статі з Київської та Донецької областей;

- зібрати зразки пухлин ЩЗ для діагностичної верифікації та можливих майбутніх генетичних і/або молекулярних досліджень; 
- зібрати букальний матеріал для пілотного дослідження;

- заповнити стандартизовану анкету з детальною інформацією про умови роботи всередині 70-кілометрової зони ЧАЕС, історію проживання всередині і поза 30-ти км зоною відчуження, споживання молока між 26 квітня та 30 червня 1986 р. і потенційні фактори нерадіаційного ризику раку Щ3 (наприклад, паління, вживання алкоголю, сімейний рак).

Для пілотного дослідження буде вибрано 100-110 випадків захворювання на рак ЩЗ у дослідних і контрольних групах (зі співвідношенням «випадок-контроль» 1:3).

\section{Публікащї}

Для оцінки радіаційно-спричиненого ризику розвитку раку ЩЗ було проведено спільне дослідження співвідношення «випадок-контроль» у когорті білоруських, російських та прибалтійських УЛНА, яке включало 107 випадків та 423 контроля [31]. Було встановлено статистично значущий взаємозв'язок «дозавідгук» із загальною дозою опромінення ЩЗ. Ексцес відносного ризику на 100 мГр становив 0,38 (95\% довірчий інтервал 0,10, 1,09).

Розглянута роль регулюючих органів та консультативних організацій в оцінці ризиків шкідливих впливів радіаційного опромінення залежно від статі, віку на момент експозиції, часу після опромінення, стану здоров'я та інших пов'язаних із цим змінних [32]. Акцентовано увагу на ризику розвитку раку, що необхідно враховувати для досягнення ефективного захисту від радіації та планування заходів щодо реагування на майбутні ядерні аварії.

У когорті з 150813 УЛНА було виявлено 196 випадків раку ЩЗ із загальним стандартизованим показником захворюваності 3,50 [95\% довірчий інтервал 3,04, 4,03] [33]. Значно вищий показник спостерігався в УЛНА, які працювали на ЧАЕС в 1986 році, коли рівень зовнішнього i внутрішнього опромінення був найвищий. Отримані результати підтверджують дані про збільшення частоти раку ЩЗ серед цієї категорії.

Parental irradiation of Ukrainian cleanup workers and evacuees and germline mutations in their offspring (Trio study)

\section{Опис дослідження}

Заплановане дослідження до 450 родин із трьох членів (батько, мати, дитина), в якій принаймні один із батьків зазнавав опромінення внаслідок аварії на ЧАЕС як УЛНА (середня доза $\geq 100$ мГр) та/або евакуйований із забрудненої території (середнє значення $\geq 50$ мкГр) [34]. Конкретні цілі полягають у дослідженні швидкості трансгенерації та нової мутації спектру генетичних варіантів у трьох членів, зокрема, перегляд ефектів у дітей та відображення їх можливого батьківського походження хромосоми. Будуть використані найсучасніші геномні технології для характеристики ландшафту геномів трьох членів родини (родинного тріо «батько-мати-дитина»), щоб визначити, чи є зв’язок між опроміненням батьків і генетичними мутаціями, що передаються нащадкам, дослідження коефіцієнтів мутацій de nого, мінісателітних мутацій, кількості змін копій та змін довжини теломерів. Аналіз буде проведено в зразках периферичної крові та/або щоки родинного тріо «батько-мати-дитина». Дози опромінення статевих залоз від часу аварії до моменту запліднення будуть реконструйовані для всіх батьків із використанням наявних записів, доповнених даними інтерв'ю. Обом батькам буде запропоновано заповнити загальну анкету для отримання демографічних даних та даних про спосіб життя. Висновки дослідження сприятимуть розумінню спадкових наслідків радіаційного впливу середньої та низької дози в людини та прогнозуванню радіаційного ризику.

\section{Публікащї}

Показано статистично значуще в 1,6 раза збільшення частоти мутацій у зародковій лінії опромінених батьків у сім'ях із радіоактивно забруднених після аварії на ЧАЕС сільських районів Київської та Житомирської областей, тоді як частота мутацій у зародкової лінії опромінених матерів не була підвищеною (контролем слугували сім'ї, де діти були зачаті до аварії на ЧАЕС) [35]. Ці дані, свідчать про підвищений рівень мінісателітних мутацій внаслідок радіоактивного впливу аварії на ЧАЕС. Обговорюються механізми індукції мутацій у мінісателітних локусах людини.

В огляді дана оцінка даним щодо мутаційного ризику радіаційного опромінення зародку, визначеного молекулярним аналізом тандемних повторів локусів ДНК: мінісателітів у людини та простих тандемних повторів у мишей [36]. Припускають, що мутаційні 
Огляди

механізми, ймовірно, різняться між двома видами, тому слід бути обережним при прогнозуванні ефектів для людини за допомогою даних, отриманих на мишах.

Розглянуто вплив променевої терапії та хіміотерапії на здоров'я потомства в людських популяціях [37]. Наявні дані свідчать про те, що здоров’я людини не зазнало істотного трансгенераційного впливу радіації.

\section{Висновки}

1. Станом на 31 березня 2020 р. на сайті ClinicalTrials.gov була розміщена інформація про 6 клінічних досліджень із медичних наслідків аварії на Чорнобильській АЕС.

2. Середня тривалість досліджень становить 15 років і 9 місяців, а 2/3 із них виконуються понад 20 років.

3. Поточний статус досліджень: «завершено»3 дослідження, «набір», «активний, без набору» $\mathrm{i}$ «призупинено» - по 1 дослідженню.

4. 4 дослідження проводяться в Україні: 3 - на базі ДУ «Національний науковий центр радіаційної медицини НАМН України» і 1 на базі ДУ «Інститут ендокринології та обміну речовин ім. В.П. Комісаренка НАМН України».

5. У всіх дослідженнях головний дослідник є співробітником Національного інституту раку США (National Cancer Institute, USA).

6. Спонсором всіх досліджень є Національний інститут раку США.

7. Тип дослідження у всіх випадках був обсерваційний.

8. За типом моделі дослідження розподіл наступний: когортне дослідження -2 дослідження, «випадок-контроль» - 2, дослідження сімей -1 (для одного дослідження інформація відсутня).

9. За часовою перспективою дослідження були ретроспективними - 3 дослідження, проспективними і поперечними - по 1 дослідженню (для одного дослідження інформація відсутня).

\section{Список використаної літератури}

1. Shore RE. Issues and epidemiological evidence regarding radiationinduced thyroid cancer. Radiat Res. 1992 Jul;131(1):98-111.

2. Jacob P, Bogdanova TI, Buglova E, Chepurniy M, Demidchik Y, Gavrilin Y, Keningsberg J, Meckbach R, Schotola C, Shinkarev S,
Tronko MD, Ulanovsky A, Vavilov S, Walsh L. Thyroid cancer risk in areas of Ukraine and Belarus affected by the Chernobyl accident. Radiat Res. 2006 Jan;165(1):1-8.

3. Tronko M, Kravchenko V, Fink D, Hatch M, Turchin V, McConnell R, Shpak V, Brenner A, Robbins J, Lusanchuk I, Howe G. Iodine excretion in regions of Ukraine affected by the Chornobyl Accident: experience of the Ukrainian-American cohort study of thyroid cancer and other thyroid diseases. Thyroid. 2005 Nov;15(11):1291-7.

4. Likhtarov I, Kovgan L, Vavilov S, Chepurny M, Ron E, Lubin J, Bouville A, Tronko N, Bogdanova T, Gulak L, Zablotska L, Howe G. Post-Chernobyl thyroid cancers in Ukraine. Report 2: risk analysis. Radiat Res. 2006 Aug;166(2):375-86.

5. Иванов ВК, Цыб АФ, Питкевич ВА, Максютов МА, Матвеенко ЕГ, Хвостунов ИК, Растопчин ЕМ, Сорокин ВС, Иванов СИ, Лешаков СЮ, Ширяев ВИ, Боровикова МП, Эфендиев ВА, Квитко БИ, Шибата У, Ямашита С, Хоши М. Формирование когорты для долговременного медицинского наблюдения и оценки радиационных рисков заболеваний щитовидной железы в рамках совместного проекта между Мемориальным фондом здоровья Сасакавы и МРНЦ РАМН. Радиация и риск. 1996;(8):93-109. (Ivanov VK, Tsyb AF, Pitkevich VA, Maksyutov MA, Matveenko EG, Khvostunov IK, Rastopchin EM, Sorokin VS, Ivanov SI, Leshakov SJ, Shiryaev VI, Borovikova MP, Efendiev VA, Kvitko BI, Shibata U, Yamashita S, Hoshi M. Forming a cohort for long-term medical observation and radiation risk assessment of thyroid diseases as part of a joint project between the Sasakawa Memorial Health Fund and the MRRC RAMS. Radiation and risk. 1996;(8):93-109).

6. ClinicalTrials.gov. http://www.clinicaltrials.gov.

7. ClinicalTrials.gov: Background / http://www.clinicaltrials.gov/ ct2/about-site/background.

8. ClinicalTrials.gov: Trends, charts, and maps / http://www. clinicaltrials.gov/ct2/resources/trends.

9. ClinicalTrials.gov. Home. Search Results. Chernobyl. https:// clinicaltrials.gov $/$ ct $2 /$ results? cond $=\&$ term $=$ Chernobyl \& $\operatorname{cntry}=\&$ state $=\&$ city $=\&$ dist $=$

10. The Agency for Healthcare Research and Quality. https://search. ahrq.gov/search?q=patient+registry

11. Ross JS, Mocanu M, Lampropulos JF, Tse T, Krumholz HM. Time to publication among completed clinical trials. JAMA Intern Med 2013 May 13; 173(9):825-8

12. ClinicalTrials.gov. Home. Search Results. Study Records Detail. International Cooperation for Post-Cherynobyl NIS Thyroid Tissue and Data Banks: https://clinicaltrials.gov/ct2/show/NCT 00339274? term $=$ Chernobyl \&draw $=2 \&$ rank $=4$

13. ClinicalTrials.gov. Home. Search Results. Study Records Detail Scientific Protocol for the Study of Thyroid Cancer and Other Thyroid Disease in Belarus Following the Chernobyl Accident: https://clinicaltrials.gov/ct2/show/NCT00339716?term=Cherno byl\&draw $=2 \&$ rank $=2$

14. Drozdovitch V, Minenko V, Golovanov I, Khrutchinsky A Kukhta T, Kutsen S, Luckyanov N, Ostroumova E, Trofimik S, Voillequй P, Simon SL, Bouville A. Thyroid dose estimates for a cohort of Belarusian children exposed to 131I from the Chernobyl accident: assessment of uncertainties. Radiat Res. 2015 Aug;184(2):203-18.

15. Little MP, Kwon D, Zablotska LB, Brenner AV, Cahoon EK, Rozhko AV, Polyanskaya ON, Minenko VF, Golovanov I, Bouville A, Drozdovitch V. Impact ofuncertainties in exposure assessment on thyroid cancer risk among persons in Belarus exposed as children or adolescents due to the Chernobyl accident. PLoS One. 2015 Oct 14;10(10): e0139826.

16. Zablotska LB, Nadyrov EA, Polyanskaya ON, McConnell RJ, O'Kane P, Lubin J, Hatch M, Little MP, Brenner AV, Veyalkin IV, Yauseyenka VV, Bouville A, Drozdovitch VV, Minenko VF, Demidchik YE, Mabuchi K, Rozhko AV. Risk of thyroid follicular adenoma among children and adolescents in Belarus exposed to iodine-131 after the Chornobyl accident. Am J Epidemiol. 2015 Nov 1;182(9):781-90.

17. ClinicalTrials.gov. Home. Search Results. Study Records Detail. Scientific Protocol for the Study of Leukemia and Other Hematologic Diseases Among Clean-up Workers in Ukraine Following the Chernobyl Accident: https://clinicaltrials.gov/ct2/ show $/$ NCT00341016? term $=$ Chernobyl \&draw $=2 \& \operatorname{rank}=1$ 
18. Chumak VV, Romanenko AY, Voillequй PG, Bakhanova EV, Gudzenko N, Hatch M, Zablotska LB, Golovanov IA, Luckyanov NK, Sholom SV, Kryuchkov VP, Bouville A. The Ukrainian-American study of leukemia and related disorders among Chornobyl cleanup workers from Ukraine: II. Estimation of bone marrow doses. Radiat Res. 2008 Dec;170(6):698-710.

19. Zablotska LB, Bazyka D, Lubin JH, Gudzenko N, Little MP, Hatch M, Finch S, Dyagil I, Reiss RF, Chumak VV, Bouville A, Drozdovitch V, Kryuchkov VP, Golovanov I, Bakhanova E, Babkina N, Lubarets T, Bebeshko V, Romanenko A, Mabuchi K. Radiation and the risk of chronic lymphocytic and other leukemias among chornobyl cleanup workers. Environ Health Perspect. 2013 Jan;121(1):59-65.

20. Gudzenko N, Hatch M, Bazyka D, Dyagil I, Reiss RF, Brenner A, Chumak V, Babkina N, Zablotska LB, Mabuchi K. Non-radiation risk factors for leukemia: A case-control study among chornobyl cleanup workers in Ukraine. Environ Res. 2015 Oct;142:72-6.

21. ClinicalTrials.gov. Home. Search Results. Study Records Detail. Scientific Protocol for the Study of Thyroid Cancer and Other Thyroid Disease in Ukraine Following the Chernobyl Accident: https://clinicaltrials.gov/ct2/show/NCT00341094?term=Cherno byl \&draw $=2 \&$ rank $=3$

22. Тронько МД, Пастер ІП, Замотаєва ГА, Масюк СВ. УкраїнськоАмериканський тиреоїдний проект: огляд наукових публікацій з питань епідемології, дозиметрії та йодного забезпечення. Ендокринологія. 2018 червень 20;23(2):154-66 (Tronko MD Pasteur IP, Zamotayeva GA, Masiuk SV. Ukrainian-American Thyroid Project: review of scientific publication on epidemiology, dosimetry and iodine protection. Endokrynologia. 2018 Jun 20;23(2):154-66)

23. Тронько МД, Пастер ІП, Замотаєва ГА. Українсько-Американський тиреоїдний проект: огляд наукових публікацій 3 питань клінічної патології. Ендокринологія. 2018 вересень 20;23(3):242-250 (Tronko MD, Pasteur IP, Zamotayeva GA Ukrainian-American Thyroid Project: review of scientific publication on clinical pathology. Endokrynologia. 2018 Sep 20;23(3):242-50)

24. Тронько МД, Замотаєва ГА, Пастер ІП, Масюк СВ. УкраїнськоАмериканський проект дослідження наслідків опромінення in utero внаслідок аварії на Чорнобильській AEC: огляд наукових публікацій. Ендокринологія. 2019 грудень 20;24(4):34659 (Tron'ko MD, Zamotayeva GA, Pasteur IP, Masiuk SV.The Ukrainian-American project for studying the consequences of in utero exposure to ionizing radiation as a result of the accident at the Chornobyl NPP: a review of scientific publications. Endokrynologia. 2019 Dec 20;24(4):346-59).

25. Тронько МД, Пастер ІП, Олійник ВА, Шпак ВМ, Терещенко ВП, Замотаєва ГА, Дерев'янко ГА, Чайковська ЛВ, Терехова ГМ Hatch M, Masnyk IJ, Zablotska LB. Спільний науковий Українсько-Американський Тиреоїдний Проект. III. Клініко-епідеміологічна характеристика результатів першого скринінгового обстеження учасників проекту // Ендокринологія. 2010;15(1):4-19 (Tronko MD, Pasteur IP, Oliynyk VA, Shpak VM, Tereshchenko VP, Zamotayeva GA, Derevyanko AA, Chaikovska LV, Terekhova GM, Hatch M, Masnyk IJ, Zablotska LB. Joint scientific Ukraine-USA Thyroid Project. III. Clinical and epidemiological characteristic of the results of first screening examination of study subjects // Endokrynologia. 2010;15(1):4-19).

26. Brenner AV, Tronko MD, Hatch M, Bogdanova TI, Oliynik VA, Lubin JH, Zablotska LB, Tereschenko VP, McConnell RJ, Zamotaeva GA, O'Kane P, Bouville AC, Chaykovskaya LV, Greenebaum E, Paster IP, Shpak VM, Ron E. I-131 dose response for incident thyroid cancers in Ukraine related to the Chornobyl accident. Environ Health Perspect. 2011 Jul;119(7):933-9.

27. Tronko M, Brenner A, Bogdanova T, Shpak V, Hatch M, Likhtarev I, Bouville A, Olijnyk V, Zamotayeva G, Drozdovitch V, Zurnadzhy L, Little M, Tereshchenko V, Chanock S, Mabuchi K. Thyroid Cancer Risk in Ukraine Following the Chernobyl Accident (The Ukrainian-American Cohort Thyroid Study). Thyroid Cancer and Nuclear Accidents Long-Term Aftereffects of Chernobyl and Fukushima. Chapter 8. Publisher: Elsevier, Editors: Shunichi Yamashita, Gerry Thomas. 2017:77-86.

28. Hatch M, Brenner AV, Cahoon EK, Drozdovitch V, Little MP, Bogdanova T, Shpak V, Bolshova E, Zamotayeva G, Terekhova G,
Shelkovoy E, Klochkova V, Mabuchi K, Tronko M. Thyroid Cancer and Benign Nodules After Exposure In Utero to Fallout From Chernobyl. J Clin Endocrinol Metab. 2019 Jan 1;104(1):41-8.

29. Hatch M, Little MP, Brenner AV, Cahoon EK, Tereshchenko V, Chaikovska L, Pasteur I, Likhtarov I, Bouville A, Shpak V, Bolshova O, Zamotayeva G, Grantz K, Sun L, Mabuchi K, Albert P, Tronko M. Neonatal outcomes following exposure in utero to fallout from Chernobyl. Eur J Epidemiol. 2017 Dec;32(12):1075-88

30. ClinicalTrials.gov. Home. Search Results. Study Records Detail. Thyroid Cancer Among Chornobyl Clean-up Workers in Ukraine: Pilot Study: https://clinicaltrials.gov/ct2/show/NCT01265381?t erm $=$ Chernobyl \&draw $=2 \&$ rank $=6$

31. Kesminiene A, Evrard AS, Ivanov VK, Malakhova IV, Kurtinaitise J, Stengrevics A, Tekkel M, Chekin S, Drozdovitch V, Gavrilin Y, Golovanov I, Kryuchkov VP, Maceika E, Mirkhaidarov AK Polyakov S, Tenet V, Tukov AR, Byrnes G, Cardis E. Risk of thyroid cancer among chernobyl liquidators. Radiat Res. 2012 Nov;178(5):425-36.

32. Mabuchi K, Hatch M, Little MP, Linet MS, Simon SL. Risk of thyroid cancer after adult radiation exposure: time to re-assess? Radiat Res. 2013 Feb;179(2):254-6.

33. Ostroumova E, Gudzenko N, Brenner A, Gorokh Y, Hatch M, Prysyazhnyuk A, Mabuchi K, Bazyka D. Thyroid cancer incidence in Chornobyl liquidators in Ukraine: SIR analysis, 1986-2010. Eur J Epidemiol. 2014 May;29(5):337-42.

34. ClinicalTrials.gov. Home. Search Results. Study Records Detail. Parental Irradiation of Ukrainian Cleanup Workers and Evacuees and Germline Mutations in Their Offspring (Trio Study): https:/ clinicaltrials.gov/ct2/show/NCT02566161?term $=$ Chernobyl\&dr $\mathrm{aw}=2 \& \mathrm{rank}=5$

35. Dubrova YE, Grant G, Chumak AA, Stezhka VA, Karakasian AN. Elevated minisatellite mutation rate in the post-chernobyl families from ukraine. Am J Hum Genet. 2002 Oct;71(4):801-9.

36. Bouffler SD, Bridges BA, Cooper DN, Dubrova Y, McMillan TJ, Thacker J, Wright EG, Waters R. Assessing radiationassociated mutational risk to the germline: repetitive DNA sequences as mutational targets and biomarkers. Radiat Res. 2006 Mar;165(3):249-68

37. Little MP, Goodhead DT, Bridges BA, Bouffler SD. Evidence relevant to untargeted and transgenerational effects in the offspring of irradiated parents. Mutat Res. 2013 Jul-Sep;753(1):50-67.

(Надійшла до редакиії 15.04.2020р.)

\section{Клинические исследования медицинских последствий аварии на Чернобыльской АЭС согласно базы данных сайта ClinicalTrials.gov}

\section{И.П. Пастер}

ГУ «Институт эндокринологии и обмена веществ им. В.П. Комиссаренко НАМН Украины»

Резюме. 26 апреля 1986 г. на четвертом реакторе Чернобыльской атомной электростанции (ЧАЭС) произошла наиболее масштабная техногенная авария в истории человечества. Цель - представить информацию о клинических исследованиях медицинских последствий аварии на ЧАЭС. Результаты. По состоянию на 31 марта 2020 г. на сайте ClinicalTrials.gov была размещена информация о 6 клинических исследованиях медицинских последствий аварии на ЧАЭС. Средняя продолжительность исследований составляет 15 лет и 9 месяцев, а 2/3 из них выполняются более 20 лет. Текущий статус исследований: «завершено» - 3 исследования, «набор», «активный, без набора» и «приостановлено» - по 1 исследованию. 4 исследования проводятся в Украине: 3 - на базе ГУ «Национальный научный центр радиационной медицины НАМН 
Огляди

Украины» и 1 - на базе ГУ «Институт эндокринологии и обмена веществ им. В.П. Комиссаренко НАМН Украины»; 1 исследование проводится в Республике Белорусь на базе Республиканского научно-практического центра радиационной медицины и экологии человека (г. Гомель), а 1 завершенное исследование проводилось в Соединенных Штатах Америки на базе Национального института рака (National Cancer Institute). Во всех исследованиях главный исследователь является сотрудником National Cancer Institute (США) Спонсором всех исследований является National Cancer Institute (США). Общее количество участников клинических исследований составило 51051 лицо (минимальное - 673, максимальное 23 143, среднее - 8508). Тип исследования во всех случаях был обсервационный. По модели исследования распределение следующее: когортное исследование - 2 исследования, исследования «случай-контроль» - 2 исследования, исследование семей - 1 исследование (для одного исследования информация отсутствует) За временной перспективой исследования были ретроспективными - 3 исследования, проспективными и поперечными - по 1 исследованию (для одного исследования информация отсутствует). За методом виборки клинические исследования были случайными (2 исследования) и не случайными (3 исследования); для одного исследования информация отсутствует. Представлен обзор 20 публикаций по результатам 5 клинических исследований.

Вывод. На сайте ClinicalTrials.gov зарегистрировано крайне малое количество клинических исследований медицинских последствий аварии на ЧАЭС.

Ключевые слова: авария на Чернобыльской АЭС, медицинские последствия, клинические исследования.

\section{Clinical studies of the medical consequences of the Chornobyl accident according to the database of the ClinicalTrials.gov website}

\section{I.P. Pasteur}

SI «V.P. Komisarenko Institute of Endocrinology and Metabolism of the National Academy of Medical Sciences of Ukraine»

Abstract. On April 26, 1986, the largest man-made accident in the history of mankind was happened at the fourth reactor of the Chernobyl Nuclear Power Plant (ChNPP). Aim is to present information about clinical trials on the medical consequences of the accident at the ChNPP is presented. Results. As of March 31, 2020, the information about 6 clinical trials on the medical consequences of the Chornobyl accident was posted at ClinicalTrials.gov. The average duration of clinical trials is 15 years and 9 months, and $2 / 3$ of them have been performed for more than 20 years. Current status of clinical trials: «completed» -3 trials, «recruiting» -1 trial, «active, not recruiting» - 1 trial, and «terminated» - 1 trial. 4 clinical trials are conducted in Ukraine: 3 - on the basis of the SI «National Scientific Center for Radiation Medicine, Natl. Acad. Med. Sci. of Ukraine» and 1 — on the basis of the SI «V.P. Komissarenko Institute of Endocrinology and Metabolism, Natl. Acad. Med. Sci. of Ukraine»; 1 clinical trial is conducted in the Republic of Belarus on the basis of the Republican Scientific and Practical Center for Radiation Medicine and Human Ecology (Gomel), and 1 completed clinical trial was conducted in the United States on the basis of the National Cancer Institute. In all clinical trials, the main researcher is an employee of the National Cancer Institute (USA). The sponsor of all clinical trials is the National Cancer Institute (USA). The total number of participants in clinical trials was 51051 people (minimum - 673, maximum - 23 143, average - 8508). The type of study in all clinical trials was observational. The distribution by research model is as follows: cohort study -2 trials, case-control studies -2 trials, family-based -1 trial (no information is available for one trial). For the time perspective, the clinical trials were retrospective -3 trials, prospective -1 trial, and cross-sectional - 1 trial (no information is available for one trial). According to the sampling method, clinical trials were random (2 trials) and non-random ( 3 trials); no information is available for one trial. A review of 20 publications based on the results of 5 clinical trials is presented. Conclusion. An extremely small number of clinical trials of the medical consequences accident at the ChNPP are registered at the website ClinicalTrials gov registered.

Keywords: accident at the Chornobyl nuclear power plant, medical consequences, clinical trials.

Для цитування: Пастер ІП. Клінічні дослідження медичних наслідків аварії на Чорнобильській АЕС згідно з базою даних сайту ClinicalTrials.gov. Ендокринологія. 2020;25(4):343-354. DOI: 10.31793/1680-1466.2020.25-4.343.

Відомості про автора: Ігор Петрович Пастер, канд. мед. наук, старш. наук. співроб., e-mail: pasteur@ukr.net, ORCID: 0000-00028199-833X.

Особистий внесок: І.П. Пастер — повна підготовка статті.

Фінансування: стаття підготовлена за власні кошти автора.

Декларація з етики: автор задекларував відсутність конфлікту інтересів і фінансових зобов'язань. 